\title{
The New Solidarity? Trade Union Coalition-Building in Five Countries
}

\author{
Carola Frege \\ London School of Economics \\ Edmund Heery \\ Cardiff Business School \\ Lowell Turner \\ Cornell University \\ INTRODUCTION
}

If mature trade union movements are to undergo revitalization, it has been frequently argued, then they must recreate themselves as social movements (Turner and Hurd 2001; Voss and Sherman 2003). They must broaden their goals to encompass social progress beyond the immediate employment relationship and rediscover their capacity to mobilize workers in campaigns for workplace and wider social justice. In Waterman's (1998: 2) words, unions should 'add to the lay trinity (liberty, equality, fraternity) the values of diversity, peace and ecological care'. Integral to this prescription of 'social movement unionism' is the belief that unions should act in concert with other progressive social forces and particularly the 'new social movements', grounded in the politics of social identity, the environment, and globalization. In short, unions must form coalitions if they are to achieve revitalization (Tohnston 2002; Robinson 2002).

Of course, unions have always built coalitions and in most developed societies what is known as the 'labour movement' embraces a complex of institutions, including political parties, trade unions, cooperative societies, research institutes, and community and welfare organizations (Wheeler 2002: 201-9). From anti-fascism in the 1930s to the civil rights and antiwar movements of the 1960s, moreover, unions have participated in coalitions of protest. Thus, coalitionbuilding is not a recent innovation, devised by new 'social movement unions', but has long formed part of labour's repertoire. Nevertheless, there is a new urgency to attempts to build coalitions in the present context. This is most apparent in the United States, where unions have joined in living wage, environmental, anti-sweatshop, and antiglobalization coalitions with a broad range of partners, drawn from faith, community, student, and environmental groups (Nissen and Rosen 1999; Russo and Corbin 1999; Johnston 2001; Hurd, Milkman, and Turner 2003: 6-8). In the United Kingdom, an established tradition of unions forging coalitions to combat the restructuring of public services (Ogden 1991; Foster and Scott 1998) has been supplemented in recent years by incipient living wage and No Sweat campaigns (Wills 2002). In Germany, there has been a strengthening of union coalitions with anti-fascist and green organizations (Behrens, Fichter, and Frege 2003: 34-5). And in Italy and Spain the traditionally broad conception of trade unionism as a force for social' and political change has been supplemented by alliances with environmental and immigrant organizations, respectively (Baccaro, Carrieri, and Damiano 2003: 51-2; Hamann and Martinez Lucio 2003: 64-5).

The purpose of this chapter is to present a framework for the analysis of union coalition-building and demonstrate its utility using comparative empirical material mainly from the United States, Germany, and the United Kingdom though we also comment on union action in Italy and Spain. In what follows, we seek to define union-coalitions and specify their 
functions, identify a variety of types of coalition and the variety of factors that encourage unions to forge coalitions. We then set out and seek to explain the variable patterns of coalition use across our five countries. The chapter concludes in speculative vein, by considering the role that coalition building should and could play in the revitalization of national labour movements.

\section{DEFINITION AND FUNCTIONS}

The founders of the academic field of industrial relations in the United Kingdom, Sidney and Beatrice Webb (1902) classified the methods of trade unionism in terms of the mechanism used to generate employment rules, or 'job regulation. Thus, unions can create and apply rules either unilaterally, or through joint decision-making (bargaining and consultation) with employers or through the method of 'legal regulation', which requires involvement in the political sphere. Coalition-building is a union method, though in many cases coalitions do not themselves give rise to job regulation. Rather, coalition can be viewed as a secondary union method that can be used to support any of the three primary methods identified by the Webbs. Thus, coalition may support unilateral regulation of the labour market, as when unions cooperate with community organizations to provide training and job search facilities for low-wage workers (Osterman et al. 2001: 118). It can support collective bargaining, as when the mobilization of community support in the course of a strike augments the union's bargaining power (Juravich and Bronfenbrenner 1999). And it can support legal regulation, as when unions mount living wage campaigns with other organizations to secure the upward adjustment of the statutory pay floor (Kusnet 1998).

Moreover, coalition is a method that can be, and often is, used to extend the reach of union activity beyond the sphere of job regulation, narrowly conceived, to pursue wider social and political change. As such, it can reinforce a broad conception of union purpose, seen particularly in the labour movements of continental Europe, and allow unions to engage as civic actors. Recent coalitions against the Second Gulf War in Italy, Spain, and Britain or coalitions to combat the extreme right in Britain and Germany provide examples. To quote another founder of UK industrial relations analysis, Allan Flanders (1970: 15-16), unions can act as a 'sword of justice' as well as a 'vested interest'.

Union coalitions can, therefore, be defined as involving discrete, intermittent, or continuous joint activity in pursuit of shared or common goals between trade unions and other non-labour institutions in civil society, including community, faith, identity, advocacy, welfare, and campaigning organizations. This is a broad definition but it excludes joint union action with state agencies and political parties and also excludes joint action between unions themselves and between unions, and employers. Union coalitions may draw state bodies, other unions and employers into joint activity but they are not defined by the involvement of institutions of this kind. The definition also specifies that coalition requires joint working with other institutions. Thus, the incorporation of new social movements into union organization through the establishment of women's or immigrant workers' sections or the embrace of new social movement goals, such as respect for the environment, in our view should not count as coalition-building. Actions of these kinds may strengthen the social movement traditions of unions and are frequently an outcome of their engagement with new social movements, but they are distinct from coalition itself. Finally, coalitions between unions and other groups rise and fall. It may be that 
the most successful coalitions run for the longer term and rest on 'bridge builders' who develop and sustain intersecting networks of labour and non-labour activists (Brecher and Costello 1990; Rose 2000) but neither permanence nor success are required by our definition.

Unions enter into coalitions for a multiplicity of purposes. Coalitions can help" them win certification/recognition from employers, provide the wherewithal to sustain strikes, help unions organize minority, or other difficult-to-contact workers and provide support for legislative change. They can also allow unions to express broader ideological and political convictions, such as support for the peace movement or sustainable development that do not have immediate employment-related consequences. Whatever the objective, however, the function of coalition partners is typically to provide unions with resources that help them to achieve goals.

In many cases unions will opt not to use these resources. Reliance on traditional resources, such as the membership's willingness to act or the support of the state or employers, which are discussed in other chapters, may be sufficient for union purposes. Coalition can be a risky tactic for unions, not least because coalition-partners may prove unreliable or have only limited capacity to advance union objectives. In many cases, the default option for unions will be not to seek coalition. Nevertheless, many unions do seek coalition partners for a wide variety of reasons. Underlying this variety, we feel is union desire to access the following five resources controlled by coalition partners:

Financial and physical resources. Coalitions can yield material support for trade unions, perhaps most obviously when women's and other support groups provide cash and food to sustain strike action (Juravich and Bronfenbrenner 1999). The involvement of coalition partners in this way has become a major feature of strikes in Britain and the United States, though is less apparent in Germany where union finances continue to be strong or in Italy and Spain where strikes rarely take the form of 'trials of strength'. In Britain, the tactic dates back to the great miners' strike against pit closures in 19845 when there was a broad mobilization of mining communities and other interest associations and identity groups in support of the strikers (Winterton and Winterton 1989). Coalitions may also provide other valuable physical resources to trade unions including networks of activists, paid staff, and premises.

Access to new groups. Many coalition partners have a constituency, membership, or client-base and the purpose of coalition can be to allow union access to those groups. Thus, community-based organizing of new union members often relies on ethnic or faith-based partners to facilitate union access to minority workers (Bonacich 2000; Milkman and Wong 2001). Another example is provided by the British Trades Union Congress (TUC) which ran a campaign on part-time work in the mid-1990s. This involved distributing information on new employment rights to part-time workers using the Citizen's Advice Bureaux, a voluntary organization with offices around the United Kingdom, used by many low paid, nonunion workers to obtain advice on employment law (Heery 1998a). The connection between Spanish unions and organizations of immigrant workers provides a final example. Here, dependence on the coalition partner for communication is particularly acute because illegal immigrants are prohibited from joining trade unions (Hamann and Martinez Lucio 2003: 65).

Expertise. Coalition partners may also possess specialist expertise upon which unions can draw. At the level of policy 
formulation, a number of German trade unions (IG BAU, IGM, Transnet) have developed policies on sustainable development for the sectors they organize in conjunction with green and environmentalist organizations. IG BAU, the construction union, which has been most active in this regard, has worked with Greenpeace to formulate a quality standard for the ecologically sound renovation of old buildings (Wieshugel 1996). At an operational level, coalition partners may supply technical advice in the fields of immigration, welfare, and other law (Needleman 1998; Milkman and Wong 2000). Thus, the campaign to unionize Mexican immigrant drywall hangers in Southern California in the 1990s drew on the legal expertise of the California Immigrant Workers' Association (Milkman 2002: 121). In Britain, the TUC's recently launched initiative on ethical trading provides another example. This campaign has involved close work with nongovernmental organizations (NGOs), such as Oxfam, which possess expertise on labour conditions in developing countries, international contacts, and a history of action on labour standards.

Legitimacy. The presence of a coalition partner can confer legitimacy on a trade union and its activities. In many cases, the function of coalition is to endorse trade unionism, particularly when faith or ethnic organizations provide backing for union organizing campaigns. Unions may also gain 'reflected legitimacy' by association with organizations, like Greenpeace, which have a positive public image among identity groups that unions are anxious to influence. Moreover, association can allow unions to shake off public suspicion that they act as a (non-legitimate) 'special interest', while joint campaigning in concert with other bodies can add weight to the union cause. For a number of years the TUC, for example, has campaigned jointly on pension reform with a range of other organizations, including Age Concern, Help the Aged, Stonewall, and the Police Federation (Heery 1998 b).

Mobilization. Coalition may facilitate the mobilization of popular support for trade unions and the policies they espouse in demonstrations, voting or consumer boycotts. Again, action of this kind has been apparent in union organizing campaigns in the United States, where faith and community organizations have rallied their supporters against the employer (Peters and Merrill 1998). It has also been seen in the antiwar and anti-globalization movements. The pivotal demonstration in Seattle against the policies of the World Trade Organization brought together 30,000 demonstrators organized by labour groups with 20,000 from environmental, religious, human rights, and other groups (Hawken 2000). In Britain the United Kingdom's main public service union, UNISON, has worked with tenants' organizations in Birmingham against the transfer of public housing from local authority control to new 'social landlords'. This campaign produced a resounding, tenants' vote against transfer in 2001, which protected public service jobs, and has provided the basis for further cooperation. In 2002 when UNISON organized national strike action in furtherance of a pay dispute, Birmingham tenants supported the action and joined the union's demonstration in the city. A final example can be seen in the living wage movement in the United States. Here, unions have joined with a broad range of other organizations to mobilize popular support and voting power for the passing of living wage ordinances by city governments, with successes being registered in cities across the States (Figart, Mutari, and Power 2002: 195-7; Hurd, Milkman, and Turner 2003: 106).

In sum, we regard coalition as a secondary method of trade unions that is used to support the primary activities of organizing and servicing members, engaging with employers and participating in the political process. It rests on the process of alliance building with other institutions and associations that operate in civil society, either for the shorter or 
the longer term. Coalitions can be used to advance a broad set of substantive goals, but at its heart lie union attempts to access the resources controlled by their coalition partners. The latter include physical and financial resources, networks of communications, expertise, legitimacy, and the capacity to mobilize constituencies and popular support.

\section{TYPES OF COALITION}

Not all union-backed coalitions are the same. Coalitions differ in life span, the identity of the coalition partner or partners, their goals, methods, and degrees of success. Given that coalitions rest on an exchange between unions and non-labour organizations, however, the task of classification can best begin by noting the variable pattern of interaction between coalition partners. At one extreme, the interests of the union may dominate, while at the other unions may accede priority to the interests of their coalition partner. In between, a number of intermediate positions are possible, and on this basis we believe that three main types can be identified as follows and can be found across all five countries:

Vanguard coalitions. Here, unions seek coalition on the basis of partners accepting a subordinate role, in which they offer solidarity and support for union objectives. In this situation, it may be assumed that the activities of the union embody a general progressive or class interest to which other groups and institutions should lend support. The union, in other words, constitutes a vanguard, which demands, or is deserving of, the solidarity of its coalition partners. Vanguard coalitions of this kind often form in the context of major 'trials of strength', long and bitter industrial disputes which are backed by support groups and a range of other organizations that lend assistance to strikers (Juravich and Bronfenbrenner 1999). The union may actively appeal for this support, but generally it is offered on an unconditional basis and it is rare for the views of supporting partners to influence strike strategy. The best documented example in Britain is probably the miners' strike of $1984 / 85$, which was sustained for months by the mobilization of mining communities and other sympathetic groups (Adeney and Lloyd 1986; Winterton and Winterton 1989). At the heart of this mobilization were the women's support groups and although the union's leadership proposed a change to the National Union of Mineworkers (NUM) constitution to allow representation of these groups, this was resisted by the constituent regions of the union, which were anxious not to surrender control of strike strategy. Support was welcome but on the basis of solidarity not shared decisionmaking.

Common-cause coalitions. This second type of coalition is characterized by an attempt to identify separate but associated interests behind which a coalition can form. The union enters the coalition to advance its distinctive interests, while its nonlabour partners do the same. The two sets of interests are complementary and as such provide a basis for cooperative, joint action. Many union-backed coalitions take this form. The UNISON campaign to block the transfer of social housing in Birmingham, described above, provides an example. In this case, the union was motivated by a desire to maintain secure jobs in the public sector and to prevent the fragmentation of its own organization as the city's large housing department was broken up into a series of non-profit making 'social landlords'. The coalition partner, the tenants' organizations, in contrast were concerned primarily about future rent rises and the possibility of housing stock being demolished and land sold to generate revenue. Both sets of interests sustained the joint campaign to win a 'no' vote and block the city's proposals to restructure the housing service. In the United Kingdom, common cause campaigns of this kind appear to 
dominate in what is probably the most frequent context for coalition-building: efforts by unions to win client support for attempts to halt the restructuring of public services (Terry 2000: 217). The distinct but complementary interests of workers in preserving jobs and conditions and clients in preserving service quality allow coalitions to form.

The institutional expression of common-cause coalitions is often the creation of an umbrella organization by trade unions and their coalition partners. Thus, the United Kingdom's Ethical Trading Initiative brings together unions and NGOs, together with businesses that accept the objective of raising labour standards. A North American example is the Coalition for justice in the Maquilas, which has drawn US and Canadian unions into joint work with religious and community- based organizations to help organize workers in Mexico (Frundt 2002: 49-51). A final example comes from Italy, where the CGIL has created centres for the promotion of the rights of transsexuals in Bologna and Turin in cooperation with the Italian Transsexuals' Movement (Beccalli and Meardi 2002: 129).

Common cause coalitions can prove unstable as the distinct interests of unions and their coalition partners move out of alignment. In the United States, there has been tension within the Alliance for Sustainable Jobs and the Environment, the umbrella organization for local coalitions on environmental issues over the appropriate response to global warming, oil drilling in Alaska and automobile mileage requirements (Moberg 1999; Rose 2000). The interest of one partner in growth and job security has proved difficult to marry to that of the other in sustainability. This is not an inevitable consequence, however, and elsewhere there is evidence of repeated interaction between unions and coalition partners leading to a broadening of their common interests. In Germany, the initial relationship between unions and the green movement in the 1970s was rather hostile, with a marked division over the issue of nuclear energy. The effect of environmental catastrophes, such as Sandoz and Tschernobyl, and the growing sensitization of the German population (including union members) to green issues, however, encouraged change in the 1980s. Today, the DGB and individual German unions engage in a broad set of coalitions with green organizations, including Greenpeace, BUND, and Deutscher Natur Ring. Partly this is based on the identification of a new common interest, as environmentally friendly production has been identified as a potential niche for German business, helping to secure jobs. This process of identifying a broader field of common interest through repeated contact has also been seen in the relationship between green organizations and unions in Italy (Baccaro, Carrieri, and Damiano 2003: 51-2). Common cause coalitions can, therefore, follow a varying trajectory, consisting of breakdown and disintegration in some cases but a broadening and deepening of contact in others.

Integrative coalitions. The third type of coalition arises when unions offer unconditional support to their non-labour partners. In this situation, the union effectively 'takes over' the objectives of non-labour organizations and accepts them as its own. This may arise when activists from new social movements achieve positions of influence in trade unions. In the United States, United Kingdom, Italy, and Germany, unions have espoused elements of a women's agenda over the past 30 years, as feminists have become active in unions and pushed for changes in policy (Beccalli and Meardi 2002: 123; Cobble and Michal 2002: 233; Koch-Baumgarten 2002: 142-4; Ledwith and Colgan 2002: 16-17). A similar development can be traced with regard to the gay, disability, and minority movements in the United States, in particular, but also in other countries (Cobble and Michal 2002: 248-50; Ledwith and Colgan 2002: 20). 
Integrative coalitions are particularly apparent in Germany, where the union movement has responded to appeals for solidarity from environmentalists and anti-fascist campaigners and participated in joint action. This type of coalition reflects the fact that trade unions are value-rational organizations; they are driven at least in part by ideology and conviction and their activists respond to requests for support on the basis of the intrinsic merits of the appeal. Nevertheless, unions must balance support for non-labour organizations against internal constraints and need to protect their institutional interests. For this reason, unions tend to form integrative coalitions when it is relatively costless for them to do so. Thus, in Germany unions have joined with national and local anti-fascist organizations to campaign against the far right in response to the intensification of neo-Nazi activity since the mid-1990s. But they have been less active in seeking to challenge racism or political extremism among their own members. Integrating or espousing the interests of coalition partners, therefore, is most likely in fields of activity which are secondary or relatively remote from the core interests of unions. In Germany, it is either unions that can gain from or are not threatened by a green agenda which have been most ready to form coalitions. Those that are threatened, such as IGBCE the chemical, mining, and energy union, have been notably less keen to take the coalition path (Kädtler and Hertle 1997). Another example is provided by Italy, where unions at national level have worked with disability organizations to promote stronger rights for disabled workers. At local level, however, where the costs of adjustment may be met in part by non-disabled workers, engagement is less evident (Beccalli and Meardi 2002: 128). This suggests that integrative coalitions may be most easily formed at higher levels of union organization where the redistributive costs of policy are less likely to be felt (Terry 2000: 224-5).

A second way of thinking about types of coalition is in terms of the methods they use. In particular, coalitions differ in how they interact with the state, the primary target of much coalition activity. According to Mcllroy (2000), trade unions can intervene in politics as 'insiders' or 'outsiders'. In the first case, they are accepted as legitimate representatives and engage in dialogue with ministers and civil servants to refine public policy, while in the second they are excluded from influence and seek to exert pressure on state agencies through industrial action or generating popular protest. This kind of distinction can be applied to labour-backed coalitions.

On the one hand, it is possible to identify 'coalitions of influence', in which unions seek coalition with other 'insider' organizations in order to make use of their expertise and legitimacy in advancing their own policy to government. The coalition-building of the TUC and DGB in recent years has largely assumed this form. It can also be seen in individual unions. The Association of First Division Civil Servants is a union of senior public servants in the United Kingdom, which has worked closely with an organization called New Ways to Work to advance its policy on family-friendly working and work-life balance. The union has run joint seminars for politicians and managers with its partner and commissioned research to identify the successful use of flexible working practices in senior management positions. New Ways to Work is an influential and expert lobbying organization and unions developing 'coalitions of influence' are likely to be drawn to partners of this kind; continuous, formal organizations that are structured and behave in a manner similar to unions themselves. In Germany, for instance, unions have largely rejected joint working with the radical, anti-globalization protest movement in favour of more limited campaigns to secure social trade clauses and codes of conduct. Thus, ver.di has affiliated to ATTAC, which is committed to the democratization of the global economy, while the DGB has joined with FIAN 
and Transfer to press German employers and government for a code of conduct to regulate the employment practices of German MNCs in developing countries.

On the other hand, we can identify 'coalitions of protest', which seek to mobilize union members and other constituencies to generate external pressure on government. The US living wage and anti-sweatshop campaigns take this form as do the attempts at community-based organizing used by Service Employees International Union (SEIU), Union of Needle Trades, Industrial and Textile Employees (UNITE), Hotel Employees and Restaurant Employees International Union (HERE), and other US unions (Needleman 1998; Bonacich 2000; Wells 2000). Coalition partners in this case may often be loosely structured, local organizations, while the union initiative may come from the activist base rather than the centre. The latter is not a hard-and-fast rule, however, and national union leaders may sanction coalitions of protest'. The Sweeney leadership of the American Federation of Labor-Congress of Industrial Organizations (AFL-CIO) has adopted this position, perhaps most notably in the Union Cities campaign (Kriesky 2001). The AFL-CIO Union Summer has also been important in creating connections between student activists and the labour movement, which have come to fruition in the anti-sweatshop movement. The costs of the umbrella organization for the movement, moreover, United Students Against Sweatshops, have been underwritten by UNITE. Even the risk-averse British TUC has sponsored coalitions of protest' and in the 1990s worked jointly with a broad range of anti-racist and black organizations to campaign against the extreme right in the East End of London. Choices over coalition tactics do not map one-to-one onto structural positions within the labour movement.

To summarize, coalitions can be classified on several dimensions, but we believe that it is useful to focus on two aspects. The first is the relationship between trade unions and their coalition partners, which can be based on a demand for solidarity, the identification of common interests or the adoption of the coalition partner's goals. The second dimension refers to the degree of integration of the coalition into state policy-making, where we distinguish coalitions-ofinfluence and coalitions-of-protest. Either type can be combined with the three forms of relationship with coalition partners.

\section{FACTORS PROMOTING COALITION}

Our analysis of the five national cases suggests that two types of pressure encourage unions to enter coalition with non-labour organizations. The first type arises mainly within unions themselves and effectively 'pushes' union strategy towards coalition. Unions are more likely to engage in coalition, when they are faced with exclusion from other kinds of resource, when their policy agenda is broadening to include non- traditional issues, when their activist base includes a significant proportion of 'bridge builders' with experience of other social movements, or when union purpose is conceived in terms of broader social change. The second type of pressure arises beyond trade unions and has to do with the supply of coalition partners and political opportunities for using coalition to effect change. The critical variables in this case therefore are the strength of civil society and the structure of the state, factors that can 'pull' trade unions towards experiment with coalition. 


\section{Diminishing Resources}

Accounts of union-backed coalitions often stress the difficulties encountered in marrying different structures, cultures and goals (e.g. Needleman 1998). For this reason, unions may eschew coalition when they have ready access to other resources and traditional methods continue to yield results. The search for coalition therefore may be a function of union decline; a method adopted in extremis. This principle can be illustrated with three examples. Accounts of coalition in the US literature are most common in two circumstances, living wage campaigns and attempts to organize low-wage workers (Turner and Hurd 2001). It is when unions seek to represent workers with low organizational power' (capacity to sustain collective organization) and low 'positional power' (low skills and secondary labour market positions) that they are most likely to turn to coalition (Edwards and Heery 1989:10-11). In other words, when unions cannot rely upon the organizational and bargaining strength of workers themselves they look for other resources, for coalition partners, to advance their goals.

In Britain, experiments with coalition developed after the election of the radical rightwing government of Margaret Thatcher. The 1980s were characterized by Crouch (1986) as a period of 'union exclusion' when unions were denied legitimacy and access to political influence by the governing party and it was in this context that experiments with coalition began. Unions tried to use vanguard and common cause coalitions in a series of largely unsuccessful attempts to block the privatization and restructuring of public services. Significantly, with Labour's return to power in 1997 there has been some slackening of this effort as unions have partly re-acquired 'insider' status. Although there is an incipient living wage campaign in Britain, the core union effort on wage regulation has been exercised within the tripartite Low Pay Commission, which recommends the level of the minimum wage to government. And while community support has been a feature of some recent organizing campaigns, unions have preferred to rely on traditional direct approaches to employers and the new statutory certification procedure to organize non-union sites. There is disenchantment with New Labour in the union movement and this has prompted continued resort to coalition, like UNISON's Birmingham housing campaign. To date though this has been a minority response.

Germany also provides evidence to support the 'resource-based' view of coalition. Although the German trade union movement is in decline, it has not faced the challenge to its legitimate status experienced by its counterparts in the liberal-market economies and public policy and the framework of employment law has remained broadly supportive. Accepted as a social partner by government and as an industry- level bargaining partner by most employers, German unions have been under least pressure to embrace coalition. When they have used the method, it has taken the form of integrative coalitions concerned with very important issues but not vital union interests. Coalition in this case has been a supplementary method, used to develop novel policy, by a union movement enjoying a high level of institutional security.

\section{Expanding Interest Representation}

German unions have turned to coalition partners as they have broadened their policy of interest representation to embrace international labour standards, anti-fascism, and environmental protection. The same pattern can be seen in Britain, where unions have worked with coalition partners to promote a new agenda of work-life balance and family- 
friendly legislation. It can also be seen in Italy or Spain, where coalitions have formed over environmental protection and immigration.

These coalitions may occur for two reasons. First, unions may lack expertise or other resources that are necessary for effective representation in these areas and be dependent on their partners to supply what they lack themselves. As was suggested above, coalition partners may supply unions with expertise, legitimacy, access to constituencies, and a capacity for mobilization. Second, environmental protection, international labour standards, and the integration of work and family are all issues that have been colonized by social movements and advocacy organizations. As interest representation extends beyond labour's traditional agenda, unions almost inevitably become drawn into contact with preexisting campaigning and advocacy organizations. Thus, in Italy union campaigning on disability and sexuality at work has occurred alongside other groups that have a long-standing and dedicated interest in these issues (Beccalli and Meardi 2002: 128-9). It seems that as unions expand onto the territory occupied by other representative institutions the potential for coalition is increased.

\section{Activism and Leadership}

An important background to coalition-building identified in research is the presence of activists and leaders in trade unions with experience of other social movements. This theme has been especially prevalent in recent American literature. Thus, Voss and Sherman (2003: 65-9) have argued both that forming community coalitions is a distinctive feature of revitalized US union locals and that a frequent precondition of revitalization is the presence of activists with a non-union background (see also Voss and Sherman 2000). As with other research that identifies leadership change as a key influence on union behaviour (Heery 2003: 294-5), they identify a mix of generational and ideological factors at work. Older activists in revitalized locals brought experience of community and welfare rights campaigning from the 1970s and 1980s, while younger activists tended to have a background in campus and identity politics from the 1990s. Experience of Central American Solidarity Movements and Anti-Apartheid were particularly prevalent. Other research has pointed to a link between feminist activism and coalitions with women's organizations in a number of countries (Beccalli and Meardi 2002: 123; Cobble and Michal 2002: 241). At Britain's TUC, policy officers with a history of involvement in women's organizations have been instrumental in the launch of coalition-based campaigns on part-time work, work-life balance, and homeworking.

The presence of activists with a non-union background appears to have a dual significance. On the one hand, they can act as bridge builders, linking unions to the other movements in which they have experience. These activists bring a cosmopolitan' perspective to union work, acting as the nodes in multi-agency networks in a way that union leaders who are schooled solely in the traditions of the labour movement may find difficult. On the other hand, they can act as innovators introducing to unions the 'repertoires of contention' used by other movements. For Sherman and Voss (2000), these activists have helped put the 'move back in the labor movement' by transferring the skills and practices of new social movements to trade unions. A readiness to seek coalition is precisely one such practice. 


\section{Union Identity}

In a recent analysis of European trade unionism, Richard Hyman (2001) has argued that national labour movements have approximated to one of three primary identities: businessjmionism, where the union defines its sphere of representation as the market; class opposition where the union seeks to mobilize its membership for a challenge To the existing social and economic order; and integrationist unionism, where the union conceives of itself as a social partner that accepts the broad constitution of society (and a plurality of legitimate interests) but seeks reform in the labour interest Hyman takes pains to stress that each 'identity' is an ideal type and that real unions inevitably blend the different conceptions. Nevertheless, the framework is useful and can help guide the analysis of coalition-building.

Unions that approximate to the first type are arguably least likely to seek coalition. In the United States it is notable that experiment with coalition has been advocated by critics of business unionism and that use of the method has grown as the failings of business unionism have become more apparent (Turner and Hurd 2001; Voss and Sherman 2003). This suggests that coalition is likely to arise as market-oriented unions seek to change their identity and broaden their conception of union purpose, either in the direction of class mobilization or social integration. Which of these two directions is chosen will influence the form of coalition. Recent developments in Britain exemplify the route from business to class unionism. There is a strong syndicalist current on the union left in Britain, visible in Arthur Scargill's leadership of the NUM in the 1980s and also in the newer generation of left union leaders elected in opposition to New Labour (Waddington 2003: 339-40). The class identity of these traditional left unions typically finds expression in militancy rather than coalition building. Where the latter occurs it tends to take the form of a 'coalition of protest' with the union in a vanguard position. Examples can be seen in the miners' strike of 1984/85, the Liverpool dock strike of the 1990 s and recent calls for industrial action by the rail union, RMT, in support of the re-nationalization of the rail network and to halt the privatization of the London Underground. In all of these cases, union goals are assumed to have primacy because the union serves as a vehicle for class conflict; the appropriate role for other progressive forces is to lend support.

In Germany, in contrast common-cause and integrative coalitions feature more strongly, reflecting the country's tradition of social partnership. Coalition here reflects acceptance of plural interests and an established commitment to working with other groups. The non-militant tenor of coalition, moreover, is reflected in the preference for 'coalitions of influence', not protest, seen most clearly in German unions' refusal to endorse radical anti-globalization protests (and linking up with the more moderate ATTAC instead). In the United Kingdom, 'coalitions of influence' have been developed most strongly by the TUC under the definite influence of the European model of social partnership (Heery 19981;). Unions with a broad conception of their purpose, therefore, are more likely than business unions to engage in coalition-building. Attachment to class or partnership conceptions of this broader role, however, exert an additional influence and help explain the types of coalition favoured by unions.

While coalition is associated with a broadening of union purpose, the relationship between union identity and coalitionbuilding may not be unilinear. A weak propensity to form coalitions might be found, not just where union purpose is narrow but also where it is very broad. Where unions are institutionalized as encompassing, class-based organizations 
then they may eschew coalition. Of the five countries we have examined, Spain and Italy are seemingly the two with the least developed traditions of coalition-building. Other features of Spanish and Italian societies may explain this relative absence but it is likely that union identity is partly responsible. The left unions, in particular, in both countries have a tradition of broad ranging political and social activism that may serve to reduce the need for or interest in coalition with other institutions or movements (Martinez Lucio 1999).

\section{Availability of Partners}

Unions require partners if they are to form coalitions and the supply of partners is therefore an additional factor promoting coalitions. Trends here seem to face in opposing directions. On the one hand, the privatization of social life, the decay of traditional occupational communities, and the emergence of more dispersed patterns of settlement have probably served to reduce the number of potential coalition partners. Survey research in Britain (Heery et al. 2000) indicates that most union organizing activity does not involve cooperation with community bodies, probably because workers generally are not drawn from any single 'community' whose institutions can lend support. On the other hand, the strengthening of forms of identity, grounded in gender, demography, sexuality, consumption, and issue-based politics, is providing a source of fresh coalition partners. Coalitions on environmental questions can be readily concluded by German (and to a lesser degree US) unions because of the strength of the country's green movement.

The differential supply of coalition partners may also explain differences in the extent of coalition across countries. In the United States, unions have been able to ally with student organizations in the anti-sweatshop campaign, reflecting the continuing vitality of student politics (albeit supported by programmes like Union Summer). In the United Kingdom, where student radicalism has substantially declined, the No Sweat campaign has failed so far to elicit a similar response. More generally, the greater religiosity of the United States, when compared with Europe (Crouch 1999), and the historical strength of American local civil society, noted since de Tocqueville, probably furnishes a stronger basis for coalition than exists elsewhere. The multiplicity of locally based community associations in the United States provides a basis for a dispersed, localized pattern of union-based coalition. At the other extreme lie Italy and Spain. According to Eurobaromtfer data both Countries have weak civil societies, as measured by the proportion of the population affiliated to associations though in Italy's case it is probable that this judgement applies mainly to the south of the country (Hamann, forthcoming: 4). Partly as a consequence, coalition features less prominently in the repertoire of collective action of the Italian and Spanish trade union movements.

\section{Political Opportunity}

The final factor that helps promote coalition is the structure of political opportunity: Unions will form coalitions when the structure of governing institutions encourages them to do so. Unions will be encouraged to form coalitions (and coalitions will be more successful) where states are structured to provide multiple points of access to policy. Thus, it is notable that living wage coalitions have developed most strongly in the United States, where there is scope for influence at city and state levels. In Britain, where there is a universal national minimum wage and local government has less autonomy, similar coalitions have been attempted but have not flourished. This may change, however, and the living wage 
movement has had most resonance in London where the first incumbent of the newly created office of mayor, Ken Livingstone, has been keen to lend backing. Livingstone has developed a contract compliance policy, which encourages public service contractors to pay living wages thereby giving fresh impetus to the campaign. In general, though, the centralized nature of the British state, coupled with an election system that tends to produce strong, majority governments, has not provided fertile ground for labour-backed coalitions. In Germany a third pattern seems to be apparent. Here, the consultative style of government, with its emphasis on involving social partners in dialogue has supported 'coalitions of influence'. On the issues of international labour standards and environmental protection, the German state has endeavoured to involve all relevant stakeholders, including trade unions and NGOs.

It seems, therefore, that the degree of centralization of state decision-making primarily influences the frequency of coalition: the more decentralized is decision making the more incentive there is for unions to form coalitions to exert influence. Multiple opportunities encourage multiple experiments with coalition-building. The nature of state interaction with civil society, in contrast, influences the type of coalition. Where the state is inclusive of civil society actors, as in Germany, then coalitions of influence will tend to form (Kriesi et al. 1995: 215). Where the state is exclusive of such actors then coalitions of protest will emerge. Some of the most notable examples of the latter in recent years have been the protests against the Second Gulf War in Britain, Spain, and Italy where governments have supported the American aggression in the face of strong popular opposition.

\section{NATIONAL PATTERNS}

The lack of systematic evidence on union coalition-building across our five countries means that it is difficult to specify national patterns with certainty. Nevertheless, evidence that is available suggests that there are differences both in the level and form of coalition-building across the national cases, though our summary of these patterns is necessarily speculative and to be treated with due caution.

In the United States, growth of coalition-building is most apparent though arguably the method continues to have secondary status (Hurd, Milkman, and Turner 2003: 106-8). The building of newly active coalitions-most of them at the local level, organized around a wide variety of issues-has been an important and widely discussed component of the recent revitalization attempts of the US trade union movement. Arguably, these developments have attracted such attention because of the previously isolationist stance of American unions with regard to other social movements. Most national unions in the United States (led by the AFL-CIO) sat out the social movements of the 1960s, though some local unions in cities like San Francisco, Seattle, and New York, did participate in antiwar and civil rights coalitions. As those movements declined in the 1970s, labour's limited participation (which for the most part did not include cooperation with feminist or environmental groups) also declined. In response to deep recession and plant closings in the 1980s, however, new labour- community coalitions emerged in campaigns to save jobs (Brecher and Costello 1990). On that foundation, a new wave of labour-backed coalition efforts expanded through the 1990s across a range of issues. There have been coalitions with faith, community, student, and environmental groups on living wages, labour standards, sustainable development, fair trade, union organizing, and other issues in recent years (Nissen and Rosen 1999; Russo and Corbin 
1999; Johnston 2001).

This ending of the isolation of American unions within US civil society reflects changes in their underpinning identity. There has been a partial movement from business to social movement unionism and associated redirection of policy to embrace a broader social and political agenda (Turner and Hurd 2001). The hostile political and industrial relations context, moreover, has prompted unions to seek coalition as other resources have been denied to them. Opportunities have been provided by the devolved structure of the US state, which has presented openings for unions and coalition partners to influence local legislatures. There have also been opportunities at supra-state level with the growing debate over labour standards within the framework of the World Trade Organization. The hostile context facing American labour has also shaped the form of coalition, which in the United States has often approximated to a 'coalition of protest', in which unions and their coalition partners have identified a common cause.

In the United Kingdom, coalition-building has seemingly been less prevalent. Where it has occurred it has often followed a similar pattern to the United States: unions have developed coalitions of protest in response to political exclusion and the restructuring of the public sector. These coalitions have a vanguard form, when forged by left unions, and common cause coalitions in other cases. The degree of exclusion experienced by UK unions has been less however, and since New Labour's election in 1997 there has been some withdrawal from coalition as unions have turned to more traditional routes of influence. The opportunities for lobbying and 'social dialogue' at European level have also been significant in this regard (see Behrens, Hurd, and Waddington, Chapter 7, this volume). Disillusion with New Labour is currently prompting a revival of coalition and the United Kingdom has seen the emergence of living wage and antisweatshop campaigns, based on those in the United States. There have also been renewed attempts to forge coalitions with the users of public services in order to deflect Labour-initiated restructuring. A constraint on this kind of development, however, is the centralization of the British state and the relatively limited opportunities afforded to unionbacked coalitions to make significant progress at local government level: local government is less autonomous and less vulnerable to campaigning pressure in Britain than it is in the United States. While the British pattern largely follows the American though in weaker form, there are also differences. The TUC's aspiration for social partnership on a European model and opportunities to influence state policy in the area of work-life balance (pensions, working time, family- friendly benefits) have generated coalitions of influence, alongside the more challenging coalitions of protest. In union coalitionbuilding, as in much else, the United Kingdom stands between Europe and America.

In Germany, there is a third pattern. Coalition has been an established feature of the labour movement and has largely taken an integrative form. This pattern reflects the stronger political identity of German unions, the tradition of corporatist state-union relations and the structuring of civil society, with reliance on national intermediary associations as opposed to the locally, based associations prevalent in the United States. The key opportunity afforded German unions has been the strength of new social movements, which has provided an ample supply of potential coalition partners (Meyer 1992; Kriesi et al. 1995; Krüger 2000). Coalitions with new social movements, such as the green and peace movements, emerged in the 1970s. The green movement, in particular, developed a strong political presence and by the late 1970s had forced the, initially unreceptive, unions to acknowledge environmental concerns. During the 1980s, the 
dialogue became more cooperative and more recently German unions have formed coalitions with anti-fascist campaigners, the unemployed, and elements of the anti-globalization movement.

The defensive coalitions against restructuring and the privatization of public services seen in Britain and the organizing coalitions seen in the United States are not apparent in Germany. This probably reflects the greater institutional security of German unions. Also reflecting this greater security is the tendency for German unions to forge coalitions of influence, not protest. The identity of German integrationist unions and the practice of social partnership have both reduced the need for, and shaped, the form of union-backed coalition.

The final pattern is seen in both Italy and Spain. The most striking feature here is the relative absence of coalition. There have been recent instances of unions in both countries acting in concert with identity, peace, and anti-globalization campaigners. But these developments are not central to attempts to revitalize unions in either country and arguably are marginal to their primary concerns. The explanation lies in large part in the environment of both union movements. Civil society is weakly organized, particularly in Spain, and the profusion of potential coalition partners seen in the United States is absent in these cases. Moreover, while traditions of social partnership are less established in Spain and Italy than they are in Germany, unions enjoy a fairly high degree of institutional security. Election procedures at workplace level provide a test of union legitimacy and allow unions access to state resources. Given this support, there is less incentive for unions to seek alliances with other institutions in civil society; there is less need to borrow the power of other movements. The pattern also reflects the identity of unions in these two countries. There is a strong, class identity to the union movement in both cases; unions are energetic political actors, embracing a broad agenda of interest representation, and frequently incorporate issues of new social movements in their political agendas. In this they share characteristics with German trade unions. In Spain and Italy, however, a broad conception of union purpose tends to be allied to a vanguardist position, which precludes the active search for coalition partners. For example, unions in Spain have a history of action on housing and other urban development issues, but this has tended to occur under the umbrella of left political parties rather than through direct coalition with urban social movements (Martinez Lucio 1999).

To conclude, on the available evidence it is possible to identify different national patterns of coalition-building, in terms of both the level of activity and its form. National union movements differ in the extent to which they resort to coalition, their stance towards potential coalition partners and the degree to which coalitions assume a mobilizing or influencing form. These patterns, in turn reflect the different identities and contexts in which unions operate. The pressure to forge coalitions is strong where unions face hostile governments and employers, while the opportunity to use the tactic arises where civil society is strongly organized and the state is decentralized. A hostile context also encourages coalitions of protest, while the reverse is true where the state seeks to govern through dialogue with social partners. In this context coalitions of influence tend to form. The effects of union identity are twofold. Recent coalition-building is a feature of unions, like those in the United States, which have moved from a strong market orientation to a broader conception of union purpose. In Europe, in contrast, where union purpose has long been broadly defined, coalition building is shaped by the nature of this definition. Where union identity contains a strong class element then there is both less resort to coalition and a preference for vanguard coalitions and coalitions of protest where the method is used. Where there is a strong 
'social' or partnership orientation, in contrast, coalitions tend to be integrative and to take the form of coalitions of influence.

\section{CONCLUSIONS}

What lessons can be drawn from this survey of coalition-building for the revitalization of labour movements? We feel that several, albeit rather mixed, conclusions can be drawn, birst, while coalition is not a central strategy of revitalization in any of the countries studied, we believe its use is likely to increase. Partly, this is because union movements are being pushed towards coalition. Across the developed world unions have experienced membership decline, and $\mathrm{m}$ many cases have lost influence in the labour market and political system. As a result, they are under pressure to develop new tactics and access new resources. In certain respects, coalitions are a symptom of weakness and unions will experience pressure to seek coalition partners if that underlying weakness remains.

Unions are also under pressure to broaden their policy agenda and engage with the questions of environmentalism, identity politics, work-life balance, globalization, and international labour standards. Dealing with all of these questions points towards coalition with other institutions that can offer unions legitimacy, expertise, and other resources. As unions are drawn onto the terrain of other social movements, necessarily, the issue of coalition will emerge. Moreover, union identities are changing and there is greater readiness to accept diversity of interests and an agenda founded on inclusive rather than exclusive definitions of solidarity (Selmi and McUsic 2002). A significant change in union government in recent years has been the development of identity politics and specialist structures for the representation of women, minority, immigrant, gay and lesbian, and other groups among the workforce (Ledwith and Colgan 2002). Developing coalitions with non-labour organizations is perhaps the logical external corollary of this internal change.

Finally, developments beyond the labour movement are likely to pull unions towards coalition. Coalition partners are likely to remain in ready supply, at least in certain fields. The issues of globalization and the regulation of labour standards, gender equality and work-life balance, internationalism, environmentalism, and anti-fascism, with their associated campaigning, advocacy and membership groups will loom large in progressive politics for the foreseeable future. Opportunities for coalition-building also seem set to grow as a result of the double-shift in the structures of government, downwards to regional and city level and upwards to the international level. At these sites, conventional party politics and the link between unions and traditional leftwing parties are less apparent. New forms of union action, founded on coalition, may prove to be more effective above and below the nation state (Ludlam and Taylor 2003).

Second, in terms of the link between coalitions and union revitalization, it can be noted that coalition has frequently represented an innovation in union strategy in the sense of a novel departure in tactics and a broadening of objectives. This is particularly true of the United States but applies in the other countries as well. If for this reason alone, coalition-building is a welcome development. Beyond this point, however, it is difficult to specify the contribution coalitions can make to union revitalization. Partly, this is because of the secondary status of coalition as a union method that is used in conjunction with other primary methods, such as political action or organizing. Partly, too it arises from the multiform nature of coalition-building. Union-backed coalitions are not all the same, but reflect different national contexts 
and union identities. It follows that the effectiveness of particular forms of coalition will depend on factors that are contingent to union movements and to their environments. In the United States, it has been noted that the most effective coalitions are those that rely upon bridge-builders, involve rank and file mobilization, and leadership support and endure, evolving through iterative action (Brecher and Costello 1990; Hurd, Milkman, and Turner 2003). Our information from the other four cases is just too sketchy to pronounce with certainty whether these same conditions underpin success elsewhere.

Our final conclusion returns once again to this theme of national differences. Advocates of social movement unionism tend to offer it as a universal solution to labour's ills, appropriate to the general context of globalization or the triumph of neo-liberal political economy. The survey of developments in Britain, Germany, Italy, Spain, and the United States suggest a need for caution before accepting this judgement. Coalition-building by unions takes different forms in different countries and reflects enduring variation in union identity and institutional context. It is unlikely that these national patterns will disappear.

\section{References}

Adeney, M. and Lloyd, J. (1986). The Miners'Strike. London: Routledge and Kegan Paul.

Baccaro, L., Carrieri, M., and Damiano, C. (2003). 'The Resurgence of the Italian Confederal Unions: Will It Last?'. European Journal of Industrial Relations, 9/1: 43-59.

Beccalli, B. and Meardi, G. (2002). 'From Unintended to Undecided Feminism? Italian Labour's Changing and Singular Ambiguities', in F. Colgan and S. Ledwith (eds.), Gender, Diversity and Trade Unions: International Perspectives. London: Routledge, 113-31.

Behrens, M., Fichter, M., and Frege, C. M. (2003). 'Unions in Germany: Regaining the Initiative?'. European Journal of Industrial Relations, 9/1: 25-42.

Bonacich, E. (2000). 'Intense Challenges, Tentative Possibilities: Organizing Immigrant Garment Workers in Los Angeles', in R. Milkman (ed.), Organizing Immigrants: The Challenge for Unions in Contemporary California. Ithaca, NY: ILR Press, 130-49.

Brecher, J. and Costello, T. (1990). Building Bridges: The Emerging Grassroots Coalition between Labor and Community. New York: Monthly Review Press.

Cobble, D. S. and Michal, M. B. (2002). 'On the Edge of Equality? Working Women and the US Labour Movement', in F. Colgan and S. Ledwith (eds.), Gender, Diversity and Trade Unions: International Perspectives. London: Routledge, 23256 .

Crouch, C. (1986). 'Conservative Industrial Relations policy: Towards Labour Exclusion?', in O. Jacobi (ed.), Economic Crisis, Trade Unions and the State. London: Croom Helm, 131-53.

-(1999). Social Change in Western Europe. Oxford: Oxford University Press.

Edwards, C. and Heery, E. (1989). Management Control and Union Power: A Study of Labour Relations in Coal-Mining. Oxford: Clarendon Press.

Figart, D. M., Mutari, E., and Power, M. (2002). Living Wages, Equal Wages: Gender and Labor Market Policies in the United States. London and New York: Routledge.

Flanders, A. (1970). Management and Unions: The Theory and Reform of Industrial Relations. London: Faber.

Foster, D. and Scott, J. (1998). 'Conceptualising Union Responses to Contracting Out Municipal Services, 1979-1997'. Industrial Relations Journal, 29/2: 137-50. 
Frundt, H. J. (2002). 'Four Models of Cross-Border Maquila Organizing', in B. Nissen (ed.), Unions in a Globalized Environment: Changing Organizational Boundaries and Social Roles. Armonk, NY: M. E. Sharpe, 45-75.

Hamann, K. (2003). 'European Integration and Civil Society in Spain'. South European Society and Politics, 8, 1: 47-68.

Hamann, K. and Martinez Lucio, M. (2003). 'Strategies of Union Revitalization in Spain: Negotiating Change and Fragmentation. European Journal of Industrial Relations, 9/1: 61-78.

Hawken, P. (2000). 'On the Streets of Seattle'. The Amicus Journal, Spring: 29-51.

Heery, E. (1998a). 'Campaigning for Part-Time Workers'. Work, Employment and Society, 12/2: 351-66.

--(1998\&). 'The Relaunch of the Trades Union Congress'. British Journal of Industrial

Relations, 36/3: 339-60.

--(2003). 'Trade Unions and Industrial Relations', in P. Ackers and A. Wilkinson (eds.),

Understanding Work and Employment: Industrial Relations in Transition. Oxford: Oxford University Press, 278-304.

--Simms, M., Delbridge, R., Salmon, J., and Simpson, D. (2000). 'The TUC's Organising

Academy: An Assessment'. Industrial Relations Journal, 31/5: 400-15.

Hurd, R. W., Milkman, R., and Turner, L. (2003). 'Reviving the American Labour Movement: Institutions and Mobilization. European Journal of Industrial Relations, 9/1: 99-117.

Hyman, R. (2001). Understanding European Trade Unionism: Between Market, Class and Society. London: Sage.

Johnston, P. (2001). 'Organize for What? The Resurgence of Labor as a Citizenship Movement', in L. Turner, H. C. Katz and R. W. Hurd (eds.), Rekindling the Movement: Labor's Quest for Relevance in the 21st Century. Ithaca, NY: Cornell University Press, 27-58.

--(2002). 'Citizenship Movement Unionism: For the Defense of Local Communities in the

Global Age', in B. Nissen (ed.), Unions in a Globalized Environment: Changing Borders, Organizational Boundaries, and Social Roles. Armonk, NY: M. E. Sharpe, 236-63.

Juravich, T. and Bronfenbrenner, K. (1999). Ravenswood: The Steelworkers' Victory and the Renewal of American Labor. Ithaca, NY: ILR Press.

Kädtler, J. and Hertle, H.-H. (1997). Sozialpartnerschaft und Industriepolitik. Opladen: Westdeutscher Verlag.

Koch-Baumgarten, S. (2002). 'Changing Gender Relations in German unions', in F. Colgan and S. Ledwith (eds.), Gender, Diversity and Trade Unions: International Perspectives. London: Routledge, 132-53.

Kriesi, H., Koopmans, R., Duyvendak, J. W, and Giugni, M. (1995). New Social Movements in Western Europe: $A$ Comparative Analysis. London: UCL Press.

Kriesky, J. (2001). 'Structural Change in the AFL-CIO: A Regional Study of Union Cities' Impact', in L. Turner, H. C. Katz and R. W. Hurd (eds.), Rekindling the Movement: Labors Quest for Relevance in the 21st Century. Ithaca, NY: ILR Press, 129-54.

Krüger, S. (2000). Arbeit und Umwelt verbinden. Zur Problematik der Interaktion zwischen Gewerkschaften und NGOs. Berlin: WZB Papers P00-521.

Kusnet, D. (1998). 'The "America Needs a Raise" Campaign: The New Labor Movement and the Politics of Living Standards', in J.-A. Mort (ed.), Not Your Father's Union Movement. London: Verso, 167-78.

Ledwith, S. and Colgan, F. (2002). 'Tackling Gender, Diversity and Trade Union Democracy: A Worldwide Project?', in F. Colgan and S. Ledwith (eds.), Gender, Diversity and Trade Unions: International Perspectives. London: Routledge, 1-27.

Ludlam, S. and Taylor, S. (2003). 'The Political Representation of the Labour Interest in Britain'. British Journal of Industrial Relations, 41/3: 729-49.

Martinez Lucio, M. (1999). 'Union Identity and Strategy in Spain: Negotiating Traditions of Struggle', in M. Upchurch (ed.), The State and Globalization: Comparative Studies of Labour and Capitalism in National Economies. London: 
Mansell, 88-112.

Mcllroy, J. (2000). 'The New Politics of Pressure-the Trades Union Congress and New Labour in Government'. Industrial Relations Journal, 31/1: 2-16.

Meyer, H.-W. (1992). 'Gesellschaftliche Zukunftsgestaltung und Soziale Bewegung'.

Forschungsjournal Neue Soziale Bewegungen 3:S8-13.

Milkman, R. (2002). 'New Workers, New Labor and the New Los Angeles', in B. Nissen (ed.), Unions in a Globalized Environment: Changing Borders, Organizational Boundaries and Social Roles. Armonk, NY: M. E. Sharpe, 103-29.

-- and Wong, K. (2000). 'Organizing the Wicked City: The 1992 Southern California

Drywall Strike', in R. Milkman (ed.), Organizing Immigrants: The Challenge for Unions in Contemporary California. Ithaca, NY: ILR Press, 169-98.

------ (2001). 'Organizing Immigrant Workers: Case Studies from Southern California', in

L. Turner, H. C. Katz, and R. W. Hurd (eds.), Rekindling the Movement: Labor's Quest for Relevance in the 21st Century. Ithaca, NY: ILR Press, 99-128.

Moberg, D. (1999). ‘Greens and Labour: Two Powerful Movements Gang Up On Polluters'. Sierra, January/February: 4654.

Needleman, R. (1998). 'Building Relationships for the Long Haul: Unions and Community- Based Groups Working Together to Organize Low Wage Workers', in K. Bronfenbrenner, S. Friedman, R. W. Hurd, R. A. Oswald, and R. L. Seeber (eds.), Organizing to Win: New Research on Union Strategies. Ithaca, NY: ILR Press, 71-86.

Nissen, B. and Rosen, S. (1999). 'Community-Based Organizing: Transforming Union Organizing Programs from the Bottom-Up', in B. Nissen (ed.), Which Direction for Organized Labor?. Detroit, MI: Wayne State University Press, 59-74.

Ogden, S. (1991). 'The Trade Union Campaign Against Water Privatization'. Industrial Relations Journal, 22/1: 20-34.

Osterman, P., Kochan, T. A., Locke, R. M., and Piore, M. J. (2001). Working in America: A Blueprint for the New Labor Market. Cambridge, MA: MIT Press.

Peters, R. and Merrill, T. (1998). 'Clergy and Religious Persons' Role in Organizing at O'Hare Airport and St. Joseph Medical Center', in K. Bronfenbrenner, S. Friedman, R. W. Hurd, R. A. Oswald, and R. L. Seeber (eds.), Organizing to Win: New Research on Union Strategies. Ithaca, NY: ILR Press, 164-77.

Robinson, I. (2002). 'Does Neoliberal Restructuring Promote Social Movement Unionism? US Developments in Comparative Perspective', in B. Nissen (ed.), Unions in a Globalized Environment: Changing Borders, Organizational Boundaries, and Social Roles. Armonk, NY:

M. E. Sharpe, 189-235.

Rose, F. (2000). Coalitions Across the Class Divide: Lessons from the Labor, Peace and Environmental Movements. Ithaca, NY: Cornell University Press.

Russo, J. and Corbin, B. R. (1999). 'Work, Organized Labor and the Catholic Church: Boundaries and Opportunities for Community/Labor Coalitions', in B. Nissen (ed.), Which Direction for Organized Labor?. Detroit, MI: Wayne State University Press, 95-112.

Selmi, M. and McUsic, M. S. (2002). 'Difference and Solidarity: Unions in a Postmodern Age', in J. Conaghan, R. M. Fischl, and K. Klare (eds.), Labour Law in an Era of Globalization. Oxford: Oxford University Press, 429-46.

Sherman, R. and Voss, K. (2000). 'Organize or Die: Labor's New Tactics and Immigrant Workers', in R. Milkman (ed.), Organizing Immigrants: The Challenge for Unions in Contemporary California. Ithaca, NY: ILR Press, 81-108.

Terry, M. (2000). 'UNISON and the Quality of Public Service Provision', in M. Terry (ed.), Redefining Public Sector Unionism: UNISON and the Future of Trade Unions. London: Routledge, 214-30.

Turner, L. and Hurd, R. W. (2001). 'Building Social Movement Unionism: The Transformation of the American Labor Movement', in L. Turner, H. C. Katz, and R. W. Hurd (eds.), Rekindling the Movement: Labors Quest for Relevance in the 
21st Century. Ithaca, NY: Cornell University Press, 9-26.

Voss, K. and Sherman, R. (2000). 'Breaking the Iron Law of Oligarchy: Union Revitalization in the American Labor Movement'. American Journal of Sociology, 106/2: 303-49.

------ (2003). 'You Just Can't Do It Automatically: The Transition to Social Movement

Unionism in the United States', in P. Fairbrother and C. B. Yates (eds.), Unions in Renewal: A Comparative Study. London: Continuum, 51-77.

Waddington, J. (2003). 'Heightening Tensions Between Trade Unions and the Labour Government'. British Journal of Industrial Relations, 41/2: 335-58.

Waterman, P. (1998). Globalization, Social Movements and the New Institutionalisms. London: Mansell.

Webb, S. and Webb, B. (1902). Industrial Democracy. London: Longmans, Green.

Wells, M. J. (2000). 'Immigration and Unionization in the San Francisco Hotel Industry', in R. Milkman (ed.), Organizing Immigrants: The Challenges for Unions in Contemporary Capitalism. Ithaca, NY: ILR Press, 109-29.

Wheeler, H. N. (2002). The Future of the American Labor Movement. Cambridge: Cambridge University Press.

Wieshiigel (1996). 'Sozialokologische Wende Als Teil Gewerksschaftlicher Reformstrategie'. GMH, 3: 150-8.

Wills, J. (2002). Union Futures. London: The Fabian Society.

Winterton, J. and Winterton, R. (1989). Coal, Crisis and Conflict. Manchester: Manchester University Press. 